\title{
The Effect of Locus of Control on Learning Achievement during the Covid-19 Pandemic
}

\section{NASIR, S., ${ }^{1 *}$ SRIYANTI MUSTAFA ${ }^{2}$, SULVIANTI $^{2}$, AND NUR AZIZAH ${ }^{2}$}

\begin{abstract}
Learning during the Covid-19 pandemic is a challenge for students and has an impact on learning achievement. This study aimed to determine the effect of locus of control on learning achievement during the covid-19 pandemic. This research was conducted at one state junior high school, Soppeng Riaja, South Sulawesi by using a quantitative approach. Data were obtained by using a questionnaire and documents of learning achievement data in the form of report cards. The collected data were then analyzed using descriptive statistics and inferential statistics. Descriptive statistical data analysis showed that the average score of student learning achievement was in the moderate achievement category, meaning that during the COVID-19 pandemic, students' learning abilities did not significantly decrease in achievement. Therefore, it was considered that students could still learn properly even though it was done online. Furthermore, the results of the analysis of the inferential data indicated that the locus of control had a positive effect on the learning achievement of students. Thus, it can be concluded that the locus of control of students while studying during the Covid-19 pandemic was quite good and had a positive influence on the progress of learning achievement.
\end{abstract}

\section{Keywords}

Achievement, locus of control, learning, , junior high school, covid-19

${ }^{1}$ Faculty member of Non-Formal Education Study Program, Faculty of Teacher Training and Education, Universitas Muhammadiyah Parepare, Indonesia; Corresponding author: nasirumpar1999@gmail.com

${ }^{2}$ Faculty member of Mathematics Education Study Program, Faculty of Teacher Training and Education, Universitas Muhammadiyah Parepare, Indonesia. 


\section{IRJE | Indonesian Research Journal in Education | | Vol. 5 | No. 2| December|Year 2021|}

\section{Introduction}

Learning is an acquired skill, and the most effective strategies are often counterintuitive (Brown, Roediger, \& McDaniel, 2014). The learning process occurs because of the interaction with the environment, meaning that learning can happen anytime and anywhere, causing changes in behavior which include aspects of changes in knowledge (cognitive), skills (psychomotor), and related attitudes (affective). The process of understanding and optimizing learning requires a thorough understanding of how learning can be facilitated and supported and how various factors can influence learning (Wei, Macfadyen, Cutler, \& Shirazi, 2019). Learning and studying are both components integrated into a series of activities that cannot be separated. A good learning process is one of success keys in education. Therefore, the teaching and learning process and the environment must be well-organized. There must be an interaction between teacher and students in the learning and teaching process. Teachers as educators have various strategies or methods to deliver materials for students in the conventional classroom and in online classes. Each use of strategy or method will certainly get different feedbacks from the students.

On the initial observation, there were students who were really interested in the materials presented to actively participate and study well. Some students passively accepted the materials, and some of them despised the materials provided by the teachers. Also, few students preferred to use any tricks in effort to avoid the tasks. Judging from the current situation, the COVID-19 pandemic has occurred, it can be a cause why students did not take the initiative to complete the tasks and only depended on their friends to finish it. However, there are also highly motivated students that were able to complete the given tasks well. Students who had the initiatives to finish the tasks were usually highly motivated in learning and gaining achievement in the study. According to data from the educational, scientific, and cultural organizations of the United Nations (Putri et al., 2020), there are at least 290.5 million students worldwide whose learning activities are disrupted due to schools being closed, including schools in Indonesia. The learning process is conducted online by utilizing various media as learning tools, such as WhatApp, Zoom, Google Meet, and various other applications. This condition requires teachers and students to master how to use learning media so that the learning process can also run smoothly. The learning process during the covid-19 pandemic was carried out according to the circular letter of the Minister of Education and Culture number 4 of 2020 regarding the implementation of education policies during the spread of coronavirus disease (covid-19), which recommended carrying out the learning process from home through online learning. Various student responses to online learning are indicated to have an impact on learning achievement. Pratiwi (2015) explained that the meaning of achievement is the results that have been achieved, carried out, or done, while study achievement itself is defined as the achievements accomplished by a student for a certain period and recorded in a school report. The type of achievement to be expressed or measured according to Syafi'i, Marfiyanto, dan Rodiyah (2018) can be observed from three aspects (1) cognitive in the form of observation, memory, understanding, application, (2) effective in the form of acceptance, respect, deepening and (3) psychomotor skills in the form of action, and verbal and non-verbal expression skills. Based on that statement, the 


\section{IRJE | Indonesian Research Journal in Education | | Vol. 5 | No. 2| December|Year 2021|}

researcher concluded that learning achievement is the result that someone has achieved; the learning process has been assessed in the form of numbers based on students' cognitive, affective, and psychomotor aspects.

\section{Literature Review}

Student achievement can be measured by looking at cognitive, affective and psychomotor aspects through the minimum completeness criteria (MCC), which is determined in accordance with the applicable curriculum regulations in schools. Additionally, Mulyani, (2013) explained that the achievements accomplished by students are the result of the interaction between the factors can influence it, both internal (in a person) and external (in one's environment). Similarly, the researcher concluded that internal and external factors influence students' learning achievement. Both of these factors are contained in a person's locus of control.

The concept of Locus of control was first put forward by Rotter (1966) that a social learning theorist. Locus of control is one of the personality variables (personality), defined as an individual's belief in his or her own ability to control (Kreitner \& Kinicki, 2005). Rotter in 1996 (Bety, 2013) stated that locus of control is a concept that explains whether a person feels that the control of their life is in their own hands (internal locus of control) or it is in the grasp of someone's hand or something else (external locus of control). Furthermore, Syatriadin (2017) argued that locus of control is individual characteristics based on the person's belief and it is determined by a combination of internal and external forces. In line with the previous opinion, Rotter (1966 as cited in Syatriadin, 2017) draws the following conclusions that locus of control is one of the personality variables, which is defined as an individual's belief whether they can control events in their life by themselves (internal locus of control) or an individual's belief that the environment is capable of controlling events in their life more than themselves (external locus of control).

It can be concluded that locus of control is a personality trait in interpreting success and failure experienced from students' internal and external factors. An important point that can be revealed in this paper is that students with an internal locus of control have a perception that the achievements achieved, both success and failure come from within themselves, the perception formed is that if you want to achieve success, you must make an effort. On the other hand, students with an external locus of control do not like to try because they believe that the success and failure experienced are determined by fate, luck, or things outside of the students. Furthermore, in this study, locus of control indicators are determined by namely 1) internal locus of control including (a) confidence in their ability to solve problems or assignments, (b) like to work hard and have more effort in solving problems or tasks and achieve achievements, and (c) have self-satisfaction in completing tasks without the help of others. 2) External locus of control includes (a) lack of effort in

achieving achievements and solving problems or tasks, (b) lack of initiative, and (c) Having the belief that success and achievement are influenced by external factors (fate), luck, environment). Sumawan (2005) explained that a student is said to have an internal locus of control orientation if he or she believes that the success and failure of everything he or she experiences are determined by his or hers efforts and abilities. At the same time, the external 


\section{IRJE | Indonesian Research Journal in Education | | Vol. 5 | No. 2| December|Year 2021|}

locus of control tends to assume that life is determined by the learners' strengths such as fate, destiny, luck, and other people in power.

Several previous researchers have discussed the influence of locus of control on student learning achievement, among others, research conducted by Dewi (2014) showed that students have a Locus of Control factor that can affect the achievement of high and better learning achievement so that it affects positively on student learning achievement. In addition, Ardianto's (2014) research also proves that locus of control affects learning achievement. The two previous studies have proven that locus of control influences student learning achievement. Furthermore, in this study, locus of control analyzed explicitly the internal and external locus of control experienced by students, including their influence on learning achievement, and compared the two forms of locus of control, to obtain in-depth information regarding their significant influence on student learning achievement.

The locus of control is an interesting issue to be discussed because it is assumed that these variables are factors that contribute to learning progress and student achievement. A genuine internal locus of control will provide a positive encouragement for students in achieving their achievements. On the contrary, an external locus of control that is not managed properly will harm student learning achievement. Therefore, this study aimed to determine the significant effect of locus of control on learning achievement.

\section{Methodology}

\section{Research design, participants, and locale of the study}

In this study, we used the ex post facto research method as the data source came from the learning processes that had been carried out previously. It was used as a basis to determine the factors that could influence the learning achievement of students.

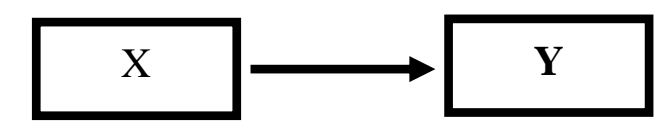

$$
\mathrm{X}=\text { Locus of Control } \mathrm{Y}=\text { Learning Achievement }
$$

Our research participants consisted of 28 students at one state junior high school, Soppeng Riaja, South Sulawesi.

\section{Data collection and analysis}

The source of the data was taken from the seventh-grade students at one state junior high school, Soppeng Riaja South Sulawesi while locus of control data were obtained using a questionnaire through a Google form while learning achievement data were obtained based on the semester report cards. The questionnaire consists of internal and external indicators of the locus of control. The internal indicators of the locus of control cover three major items (figure 1) and the external indicators of the locus of control have three major items (figure 2). The data obtained were analyzed quantitatively using the descriptive statistical 


\section{IRJE | Indonesian Research Journal in Education | | Vol. 5 | No. 2| December|Year 2021|}

analysis and inferential statistical analysis. After the data were analyzed, they were categorized to determine the level of locus of control that students had by using the following categories.

$81-100 \quad$ is categorized as very high

$61-80 \quad$ is categorized as high

$41-60$ is categorized as moderate

$21-40 \quad$ is categorized as low

$0-20 \quad$ is categorized as very low

\section{Ethical considerations}

To deal with, the ethical consideration of this study, researchers asked their participants to read an informed consent describing their readiness to participate in voluntarily during the study, including sharing their responses to be analyzed, disseminated, and published in a scientific journal. All participants' data were masked to protect their identity.

\section{Findings and Discussion}

The research was conducted during the Covid-19 pandemic, where learning interactions took place online, so the data collection process was also carried out online by utilizing various learning applications or social media. The Covid-19 pandemic has brought many changes to the learning process that has been done face-to-face. This condition raises a variety of student responses due to changes in routines which of course require a long adaptation to new habits following online learning. Likewise, the research process carried out must adapt to the conditions of students whose activities are carried out by distance learning. Researchers distributed questionnaires to students in the form of a Google Form. The questionnaire contains indicators of aspects of internal locus of control and external locus of control. The results of the Google form questionnaire data analysis provided by students are presented in Figure 1.

Figure 1. Data indicator internal locus of control

Locus of control internal

Having self-satisfaction in completing tasks without the help of others

Having happy in working hard and has more effort in solving problems or assignments and gain achievements

Having Confidence in their ability to solve problems or assignments

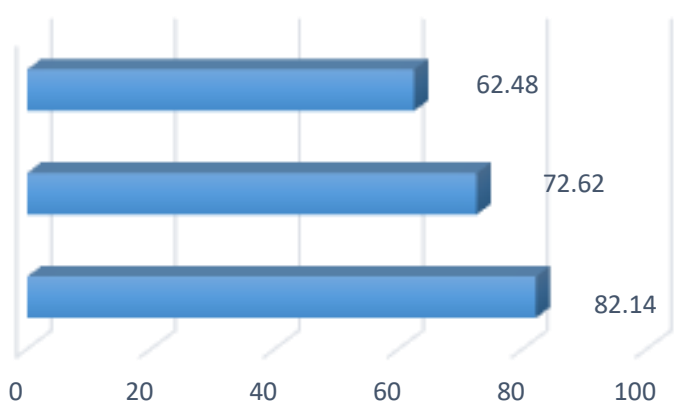




\section{IRJE | Indonesian Research Journal in Education | | Vol. 5 | No. 2| December|Year 2021|}

Figure 1 above contains the scores of students' responses to the aspects of the internal locus of control indicators. In the confidence indicator, it was concluded that the average analysis result was 82.14 which is in the very high category. It showed that students had confidence in completing the given tasks. The very high category indicates that high self-confidence has an impact on the completion of gain tasks, namely students were responsible and full of confidence in completing the tasks given. This condition is excellent for student learning progresses because it contributes positively to the achievement of learning achievement. Furthermore, the indicators like to work hard and have a business; the average acquisition of the analysis results was 72.62 in the high category. It showed that students had a high level of effort and hard work in achieving achievement and good grades. This condition was also considered good for students' learning progress because it contributes positively to the achievement of learning achievement. For the indicator of having self-satisfaction, the average score of 62.48 was in the medium category. It shows that the satisfaction obtained by students in completing their tasks can still be controlled, it means that students will be motivated to study harder with the achievement of learning outcomes. Obtaining an average score for each indicator in figure 1 above gives a conclusion that the internal locus of control of students was quite good because it tended to show a hard effort and maximizing ability to achieve success. Furthermore, the presentation of external locus of control data is shown in Figure 2.

Figure 2. Data indicator external locus of control data

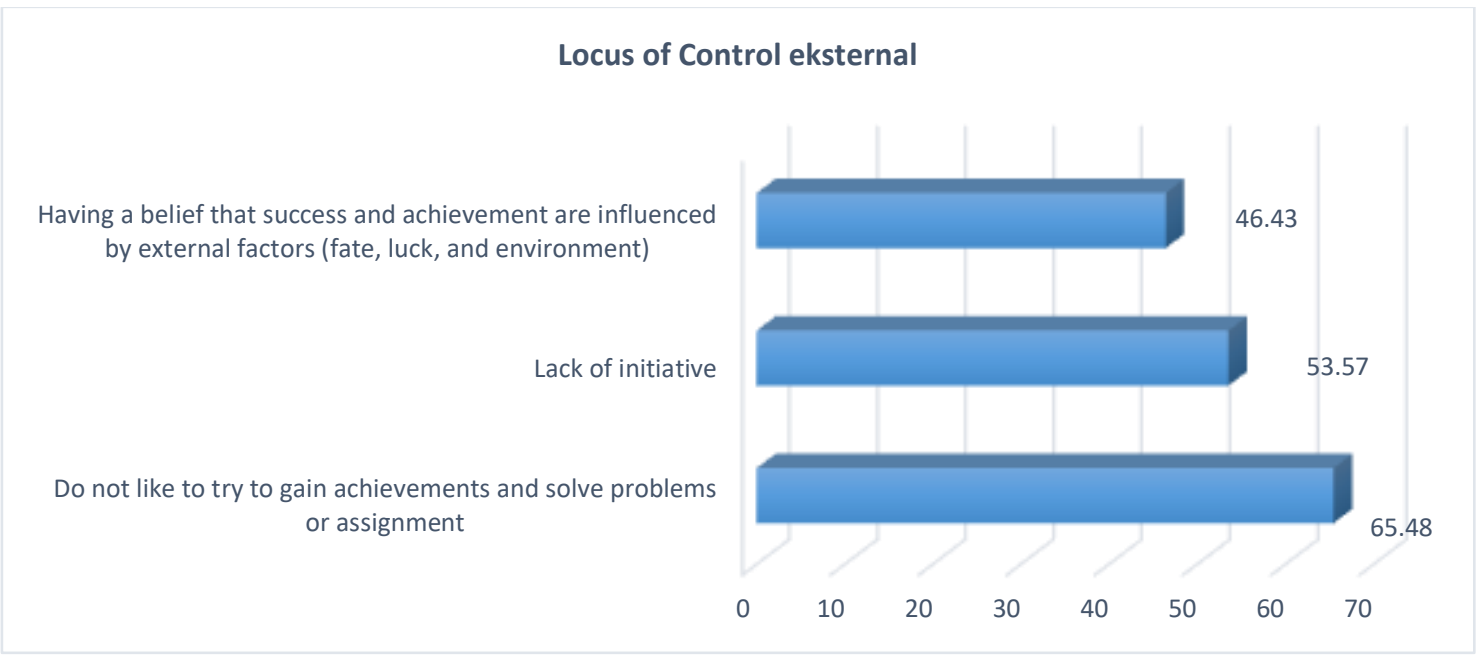

Figure 2 above contains the scores of the student's responses to the external locus of control indicators. For the indicator of not liking to try, the average analysis result was 65.48 that is in the high category. It showed that students were less trying and working hard in completing the given task. This condition contributes negatively to the learning progress of students therefore it will have an impact on achievement. Furthermore, the indicator of lack of initiative obtained an average score of 53.57 that was in the medium category. It showed that students lack the initiative in doing assignments. This condition has an impact on the 


\section{IRJE | Indonesian Research Journal in Education | | Vol. 5 | No. 2| December|Year 2021|}

achievement of mediocre learning achievement because it is not supported by high initiatives in learning. While the indicator of the confidence that is success influenced by external factors, it is concluded that the average analysis result was 46.43 in the medium category. It showed that students lacked self-confidence, even though high self-confidence will motivate students to progress in their learning so that it will have an impact on learning achievement.

The data in Figure 1 and Figure 2 above give a conclusion that the average internal locus of control of 73.01 was in the high category while the external locus of control of 55.16 was in the medium category. This condition indicates that students with an internal locus of control try harder and maximize their ability to achieve learning success, while students with a medium external locus of control hope and effort to improve their failures because they feel unable. Internal locus of control is very well developed for students because it contributes to learning achievement.

Obtaining the locus of control questionnaire scores can be used as materials for evaluating the development of students. Feist and Feist (2008) stated that too extreme scores on two dimensions (internal and external) are not good. An external locus of control that is too high can lead to hopelessness and apathy. At the same time, an internal locus of control that is too high can make a person feel responsible for everything, including those beyond their control. According to Feist and Feist (2008), a healthy locus of control is when the score is in the middle of both dimensions but leans towards internal. This statement is relevant to the acquisition score in this study, where the internal locus of control score is higher than the external locus of control score, thus placing the two in different categories, namely the internal locus of control is in the high category while the external locus of control is in the medium category. The difference between the two categories is not extreme. Therefore, the locus of control of students can still be assumed to be good. Furthermore, learning achievement data from student report cards while studying during the COVID-19 pandemic were obtained as shown in table 1.

Table 1. Data analysis descriptive statistics math achievement

\begin{tabular}{lc}
\hline Statistics & Learning Achievement Data \\
\hline Sample Size & 28 \\
Ideal Score & 100 \\
Mode & 79.00 \\
Median & 78.50 \\
Average Score & 78.52 \\
Lowest Score & 71.00 \\
Highest Score & 87.00 \\
Score Range & 16.00 \\
Standard Deviation & 2.98 \\
\hline
\end{tabular}

Table 1 shows that the number of samples in this study amounted to 28 students with 100 as an ideal score. The average score of the data obtained was 78.52. This score was obtained 


\section{IRJE | Indonesian Research Journal in Education | | Vol. 5 | No. 2| December|Year 2021|}

from the total score obtained by all students divided by the number of students. The highest score was 87.00, and the lowest score was 71.00. So, the range of student achievement data scores was 16.00. The mode obtained from the data was 79.00. It also showed that the highest frequency value of the data was 79.00. The data median showed that $50 \%$ of the data were below 78.50 and $50 \%$ of the data were above 78.50 . The data standard deviation value of 2.98 indicated that it was not too varied. Overall, the acquisition of statistical data indicated that the achievement of student learning achievements during the COVID-19 pandemic was quite good, still under control but needs to be improved. Classically $80 \%$ of the data in table 1 were assumed to be students who had mastered learning. If the students' learning achievement data scores were grouped into five criteria, the frequency distribution and the percentage of scores are obtained as shown in Table 2.

Table 2. Results of frequency distribution and percentage of learning achievement data

\begin{tabular}{lccc}
\hline Score Interval & Category & Frequency & Percentage (\%) \\
\hline $90-100$ & Very High & 0 & 0 \\
$80-89$ & High & 8 & 28.57 \\
$65-79$ & Medium & 20 & 71.43 \\
$55-64$ & Low & 0 & 0 \\
$0-54$ & Very Low & 0 & 0 \\
\hline Sum & & 28 & 100 \\
\hline
\end{tabular}

Table 2 supports the presentation of table 1, namely during the Covid-19 pandemic, student learning achievement was quite good because the frequency distribution was in the "medium" category and the "high" category, although the most significant frequency was in the "moderate" category, which was 20 with percentage 71.43 . The acquisition of learning achievement data did not conflict with the student's responses to the questionnaire data analysis. The two data sources (questionnaires and report cards) were interrelated because they showed conformity, particularly good learning achievement was obtained because of a good locus of control.

Furthermore, to determine the effect of locus of control on learning achievement, we did first - normality test which was conducted to determine whether the data under study came from a normally distributed population. For the normality test, we used the Shapiro-Wilk Test using SPSS with the following test criteria: 1) if the significant value or probability is $p \geq a$ with $a=0.05$, it can be concluded that the data are normally distributed. 2) If the significant value or probability $p<a$ with $a=0.05$, it can be concluded that the data are not normally distributed.

Table 3. Tests of normality

\begin{tabular}{lllllll}
\hline & Kolmogorov-Smirnov $^{\mathrm{a}}$ & & \multicolumn{3}{l}{ Shapiro-Wilk } \\
\hline & Statistic & Df & Sig. & Statistic & Df & Sig. \\
\hline $\begin{array}{l}\text { Learning } \\
\text { achievement }\end{array}$ & .150 & 28 & .107 & .937 & 28 & .094 \\
\hline
\end{tabular}




\section{IRJE | Indonesian Research Journal in Education | | Vol. 5 | No. 2| December|Year 2021|}

Lilliefors significance correction, table 3 shows that results of data analysis using Shapiro Wilk, learning achievement in the second semester with sig $\mathrm{p}=0.094$ was greater than the significant level $\mathrm{a}=0.05(0.094>0.05)$, so it can be concluded that the data are normally distributed, so that the normality test was fulfilled.

Linearity, this test was conducted to determine whether the two variables had a linear relationship or not. This test used a linear test ( $F$ test). If the value of sig $>0.05$, then there is a relationship between the linear variables, and if the value of sig $<0.05$, then there is no relationship between the linear variables.

Table 4. ANOVA analysis

\begin{tabular}{|c|c|c|c|c|c|c|c|}
\hline & $\begin{array}{l}\text { Sum of } \\
\text { Squares }\end{array}$ & df & $\begin{array}{l}\text { Mean } \\
\text { Square }\end{array}$ & $\mathbf{F}$ & Sig. & & \\
\hline \multirow{5}{*}{$\begin{array}{l}\text { Student's } \\
\text { Achievement } \\
* \text { locus of } \\
\text { control }\end{array}$} & \multirow{5}{*}{$\begin{array}{l}\text { Between } \\
\text { Groups } \\
\text { Within } \\
\text { Group }\end{array}$} & (Combined) & 189.583 & 6 & 31.597 & 13.229 & .000 \\
\hline & & Linearity & 177.883 & 1 & 177.883 & 74.475 & .000 \\
\hline & & \multirow{2}{*}{$\begin{array}{l}\text { Deviation from } \\
\text { Linearity }\end{array}$} & 11.700 & 5 & 2.340 & .980 & .453 \\
\hline & & & \multirow{2}{*}{21} & \multirow{2}{*}{2.388} & & & \\
\hline & & 50.158 & & & & & \\
\hline & Total & 239.741 & 27 & & & & \\
\hline
\end{tabular}

The results of the linearity test show that the sig $(\mathrm{p})$ value is 0.453 . This value is greater than the significance level $\mathrm{a}=0.05(0.453>0.05)$. So, it can be concluded that the relationship between the independent variable (locus of control) and the dependent variable (students' learning achievement) was linear. Furthermore, simple linear regression test data determines the functional relationship between the Locus of Control $(\mathrm{X})$ variable and the learning achievement variable $(\mathrm{Y})$. The regression test results are as follows.

Table 5. Linear regression test

\begin{tabular}{|c|c|}
\hline Model & Koefisien \\
\hline Konstanta $(\alpha)$ & 63.823 \\
\hline Locus of Control questionnaire score $(\beta)$ & 0.293 \\
\hline
\end{tabular}

The data analysis showed the simple linear regression formula as follows:

$$
Y^{\wedge}=63,823+0,293 x
$$

The simple linear regression equation showed that the constant value $\alpha=63.823$ and $\beta=$ 0.293 , this means:

a. If there was no locus of control $(X)$ that affects, then the estimated value of students' learning achievement $(\mathrm{Y})$ was 63.823. 


\section{IRJE | Indonesian Research Journal in Education | | Vol. 5 | No. 2| December|Year 2021|}

b. The locus of control (X) 0.293 positively affects students' learning achievement $(\mathrm{Y})$. This means that for every one per cent increase in the locus of control variable, the student's learning achievement variable increased by 0.293 . Because it is positive, it can be said that students' locus of control has a positive effect on students' learning achievement, so the regression equation was $\mathrm{Y}=63.823+0.293 \mathrm{x}$.

Table 6. Coefficients

\begin{tabular}{lllllll}
\hline Model & $\begin{array}{l}\text { Unstandardized } \\
\text { Coefficients }\end{array}$ & $\begin{array}{l}\text { Standardized } \\
\text { Coefficients }\end{array}$ & $\mathbf{t}$ & Sig. & & \\
\hline $\mathbf{1}$ & B & Std. Error & Beta & .861 & 37.014 & .000 \\
& (Constant) & 63.823 & 1.724 & & 8.647 & .000 \\
& locus of control & .293 & .034 & & & \\
\end{tabular}

A series of data analysis techniques in this study aimed to determine the effect of locus of control on student learning achievement during the covid-19 pandemic. Internal locus of control indicators with an average of 72.34 were in the high category. The ability of students who had a high internal locus of control was accompanied by the acquisition of good achievements or success, as stated by Syatriadin (2017) that success and failure experienced were determined by one's efforts and abilities or factors from oneself.

External locus of control indicators with an average analysis of 55.16 were in the medium category. The ability of students who had an external locus of control tended to blame their environment for believing that the failures that they had were caused by luck or other people around them, as stated by Robbins and Judge (2007) that external locus of control is an individual who believes that whatever happens to him or her is controlled by outside forces such as luck and chance. If the students' internal locus of control is good, it is expected that it can be a driving force for increasing learning achievement. This can be achieved by having an attitude of wanting to try, having high initiative, and willingness to work hard in working on math problems. Locus of control of students affects the achievement of higher and better learning achievement so that it has a positive effect on learning achievement. Thus, students with a good internal locus of control will have a high achievement.

During the Covid-19 pandemic, at least 290.5 million students' learning activities worldwide were disrupted due to closed schools. The action taken by many countries, including Indonesia, was to close all school activities and provided an alternative educational process for students who could not carry out the process of education in educational institutions by working from home. One of the impacts felt by students in the case of this pandemic was that the learning process must be done online. The researchers concluded that by seeing the impact of the COVID-19 pandemic, students who liked the online learning process, including the internal locus of control because they still had the initiative and effort to learn even though they faced a pandemic situation, while students who did not like the online learning process included external locus of control because the initiative to learn was reduced by blaming what is in the surrounding environment by not trying to find a solution to follow the learning process. 


\section{IRJE | Indonesian Research Journal in Education | | Vol. 5 | No. 2 | December|Year 2021|}

\section{Conclusion}

Locus of control is one of the factors that can have a positive influence on learning achievement. Students are said to have an internal locus of control orientation if they believe that the success and failure of everything they experience are determined by their efforts and abilities. In contrast, students who have an external locus of control tend to assume that life is determined by their strengths, such as fate, destiny, fortune, and other people in power. The higher the locus of control, the higher the learning achievement obtained by students. Conversely, the lower the locus of control, the lower the learning achievement obtained by students. The results of this study also serve as suggestions for other researchers to expand the scope of research objects in different fields of study so that student learning achievements during the COVID-19 pandemic continue to receive attention.

\section{References}

Ardianto, H., \& Suparji. (2014). Pengaruh locus of control dan aktivitas belajar terhadap prestasi belajar ilmu statika dan tegangan pada siswa SMKN 3 Surabaya. Jurnal Kajian Pendidikan Teknik Bangunan, 3(1), 50-58.

Bety. (2013). Pengaruh locus of control terhadap hasil belajar mahasiswa akuntansi. Jurnal Pendidikan Akuntansi Indonesia, 11(2), 11-18.

Brown, P. C., Roediger, H. L., \& McDaniel. M. A. (2014). Make it stick: The science of successful learning. Cambridge, MA: Harvard University Press.

Dewi, A. K. (2014). Pengaruh locus of control dan motivasi belajar terhadap prestasi belajar akuntansi siswa kelas xi ips sma negeri 2 sleman tabun ajaran 2013/2014 [Unpublished thesis].Universitas Negeri Yogyakarta.

Feist, J., \& Feist, G. J. (2014). Teori kepribadian. Jakarta: Salemba Humanika.

Kreitner., \& Kinicki. (2005). Perilaku organisasi. Jakarta: Salemba Empat.

Mulyani, D. (2013). Hubungan kesiapan belajar siswa dengan prestasi belajar. Jurnal Ilmiah Konseling, 2(1), 27-31.

Pratiwi, N. K. (2015). Pengaruh tingkat pendidikan, perhatian orang tua, dan minat belajar siswa terhadap prestasi belajar bahasa indonesia siswa SMK kesehatan di kota Tangerang. Jurnal Pujangga, 1(2), 75-105.

Putri, R. S., Purwanto, A., Pramono, R., Asbari, M., Wijayanti, L. M., \& Hyun, C. C. (2020). Impact of the COVID-19 pandemic on online home learning: An explorative study of primary schools in Indonesia. International Journal of Advanced Science and Technology, 29(5), 4809-4818.

Robbins, S. P., \& Judge, T. A. (2007). Organizational behavior. Saddle River, NJ: Pearson Prentice Hall.

Rotter, J. B. (1966). Generalized expectancies for internal versus external control of reinforcement. Psychol Monogr, 80,1-28. doi: 10.1037/h0092976.

Sumawan. 2005. Hubungan antara lokus kendali, pemahaman informasi karier, pretasi akademik. dengan kematangan karier siswa sma negeri kota malang. [Unpublished thesis]. Universitas Negeri Malang. 


\section{IRJE | Indonesian Research Journal in Education | | Vol. 5 | No. 2| December|Year 2021|}

Syafi'i, A., Marfiyanto, T., \& Rodiyah , S. K. (2018). Studi tentang prestasi belajar siswa dalam berbagai aspek dan faktor yang mempengaruhi, Jurnal Komunikasi Pendidikan, 2(2), 115-123.

Syatriadin, S (2017). Locus of Control : Teori temuan penelitian dan reorientasinya dalam manajemen penanganan kesulitan belajar peserta didik. Fondatia: Jurnal Pendidikan Dasar, 1, 144-164.

Wei, J., Macfadyen, L., Cutler, F., \& Shirazi, S. (2019). Implementation of learning analytics to optimize learning and learning environments: Tertiary Ins.

\section{Biographical notes}

NASIR S. is a faculty member of Non-Formal Education Study Program, Faculty of Teacher Training and Education, Universitas Muhammadiyah Parepare.

SRIYANTI MUSTAFA is a faculty member of Mathematics Education Study Program, Faculty of Teacher Training and Education, Universitas Muhammadiyah Parepare.

SULVIANTI is a faculty member of member of Mathematics Education Study Program, Faculty of Teacher Training and Education, Universitas Muhammadiyah Parepare.

NUR AZIZAH is a student of Mathematics Education Study Program, Faculty of Teacher Training and Education, Universitas Muhammadiyah Parepare. 